\title{
Paleolimnology as a Tool to Achieve Environmental Sustainability in the Anthropocene: An Overview
}

\author{
Émilie Saulnier-Talbot \\ Laboratoire de Paléoécologie aquatique, Université Laval, Québec, QC G1V 0A6, Canada; \\ emilie.saulnier-talbot@cen.ulaval.ca
}

Academic Editor: Mary J. Thornbush

Received: 2 February 2016; Accepted: 26 May 2016; Published: 30 May 2016

\begin{abstract}
Lacustrine sediment accumulation provides meaningful and diverse long-term records of environmental change. This overview highlights the usefulness of the paleolimnological approach in evaluating the magnitude and direction of human-induced environmental change in lakes and their catchments. Because of the services they provide, freshwater ecosystems have always been significantly affected by human activities. However, the rate and extent of human-induced change in continental freshwaters and their catchments has considerably increased since the beginning of industrialization (mid-18th century), and are even more pronounced since the advent of the "Great Acceleration" (since the mid-20th century). Global change, including climate and landscape changes, loss of biodiversity, species introductions and the spread of pollutants, leave traces in lake sediment archives that provide valuable long-term information with which to evaluate and quantify past environmental changes. This paper outlines how the knowledge gleaned from an interdisciplinary paleolimnological approach can benefit the development of mitigation and adaptation measures to current global change at various latitudes.
\end{abstract}

Keywords: lake sediments; anthropogenic impacts; landscape change; baseline conditions

\section{Introduction}

In recent years, the environmental research community has increasingly come to recognize the necessity of a long-term view in assessing current and future environmental change, informing sound management and conservation strategies of ecosystems and in maintaining the services that they provide [1-3]. Despite the increasing visibility of long-term approaches in basic research, more effort still needs to be injected into bridging the gap between fundamental scientific development and the applied management of ecosystems [4]. It is also important that the discussion be maintained in the scientific and applied literature, so that the ideas put forward about the necessity of long-term investigation for upholding ecosystem health become progressively better acknowledged within adaptive management programs targeting aquatic environments and their catchments. This paper provides an overview of the importance of sedimentary records from continental aquatic ecosystems, and from lakes in particular, in providing the long-term insight needed to ensure the maintenance of ecological goods and services through adaptation to current and future environmental change.

\section{Lakes as Integrators of Environmental Change}

Lakes are integrated systems that encompass dynamic interactions between geosphere, hydrosphere, atmosphere and biosphere. As such, they are superior integrators of whole landscape changes [5,6], and are especially well-suited to cross-boundary studies, such as air-water and land-water interfaces. Long-term dynamics in lakes are strongly driven by climate variability, including hydrological cycles (e.g., [7,8]) and variations in temperature (e.g., [9]) as well as by other 
environmental changes, such as soil and vegetation development (e.g., [10,11]). These processes can have multiple effects on aquatic physico-chemistry through biogeochemical cycles (see [12] for examples on carbon).They are increasingly influenced by anthropogenic stressors, including land-use changes, organic and inorganic contamination and biotic homogenization, which lead to progressively complex interactions in the functioning of lakes (e.g., [13]). Lake sediments assimilate materials that come from lake basins, including watersheds (terrestrial input) and airsheds (atmospheric input), and conserve them in a chronological sequence. Many of these materials, including biological remains, geochemical signatures of biota and pollutants, such as heavy metals, preserve well for extended periods of time (on the order of millennia) [14]. Consequently, stratigraphic signals of natural and anthropogenic change are particularly well preserved in lake sediments. Paleolimnology is the science that studies the physical, chemical and biological characteristics of lake sediments [14]. It is an interdisciplinary science that can produce highly resolved time-series data for the analysis and interpretation of environmental change at various timescales (annual to millennial; see [15], Chapter 2), offsetting the paucity of direct long-term measurements, which in most regions are often rare or altogether lacking. Good chronological control is vital to the paleolimnological approach, with higher organic sedimentation rates (or input) usually increasing temporal resolution (Figure 1). The concept of paleolimnology as a tool for effective ecosystem management is not new (e.g., [16,17]), but the approach remains marginal in its application to environmental problem-solving, despite the numerous advantages that the long-term view provides in developing more robust ecosystem management [1]. Here, a number of examples are presented that illustrate the ways in which lake sediment archives record human-induced environmental change and how, in the context of the Anthropocene epoch, the period when Earth system processes are dominated by human activities (see below), paleolimnology is becoming an indispensable tool to inform the management and conservation of freshwater ecosystems and their catchments as well as the services that they provide.

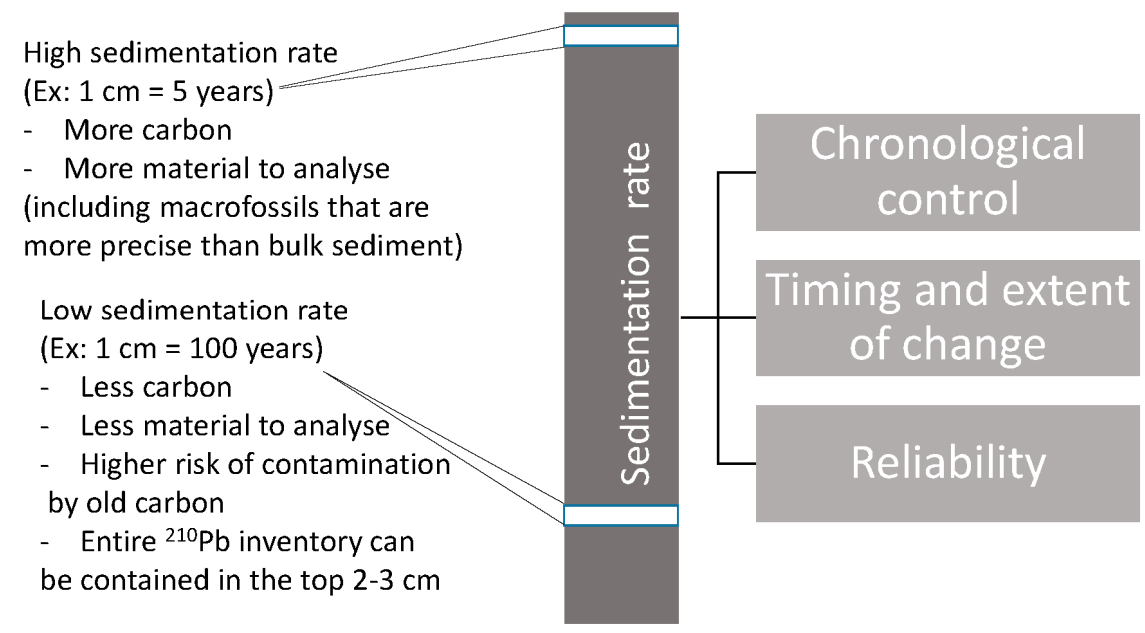

Figure 1. Sediment core chronologies ranging from around 500-45,000 years BP are most often generated using the ${ }^{14} \mathrm{C}$ method. Since organic matter is needed for this method, lake sediments that contain very small amounts of organic carbon are likely to be problematic to date (see [18]). In less productive lakes, where small accumulations can represent long periods of time (sometimes a few centuries in $1 \mathrm{~cm}$ ), short-lived changes can easily go unnoticed. Dating more recent sediments ( $<150$ years) is done using the degradation of ${ }^{210} \mathrm{~Pb}$ in the upper section of the core, but it remains difficult to obtain reliable dates between around $150-500$ years BP.

\section{Marking Out the "Age of Humans" in Time and Space}

The Anthropocene can be loosely defined as the epoch in which the key driver of change is the human modification of global environments at unprecedented rates (but see [19]). Although 
the very existence of the Anthropocene and pinpointing its beginning has been the subject of much debate, Waters et al. ([20] and citations therein) recently presented a strong case for its differentiation from the Holocene. As evidence, they cite the following anthropogenic stratigraphic markers of functional change in the Earth system: manufactured materials, fallout radionuclides and particulates from fossil fuel combustion as well as the substantial modification of the carbon, nitrogen and phosphorus cycles over the past century, extent of human perturbation of the climate and biotic changes, including worldwide species invasions and accelerating rates of extinction. They suggested that the formalization of the lower boundary of the Anthropocene should be placed in the mid-20th century, a time corresponding to what is increasingly being referred to as the "Great Acceleration" (term first used by [21,22]). A key notion of the Anthropocene is its globalism: that it can be observed around the planet. Of course, many ecosystems have been significantly modified by humans for much longer than this, but 1950 CE marks the time when a widespread signature of human impact can be detected in the global geological record [20].

While some will argue that trace pollutants record human activity but do not directly record human modification of ecologically important processes (soil erosion, nutrient enrichment, warming, acidification, etc.), there are examples that point to the sensitivity of some lakes to even small changes in trace pollutants. For example, Saulnier-Talbot et al. [23] showed that small low-tundra lakes in Northern Ungava (Canada) became more productive at the end of the 20th century, even before any sign of warming in the region. They hypothesized that this change was likely linked to increased atmospheric deposition of reactive nitrogen, as was shown to be the case for other remote arctic and alpine lakes [24]. Indeed, few lakes around the world can now be considered pristine, even the most remote, which show evidence of transitioning into the Anthropocene through various changes in the biogeochemical content of sediments $[25,26]$.

Spheroidal carbonaceous particles (SCPs) are one of the most conspicuous markers of the Anthropocene in lake sediments. These microscopic porous spheroids are produced through the process of industrial fossil fuel combustion [27]. They are deposited from the atmosphere onto lakes and their catchments, where they enter the sediment record. Because of their solely industrial origin, they provide an unambiguous human marker. Moreover, they show a global, synchronous and steep increase in accumulation starting ca. 1950 [28], concomitant with the start of the Anthropocene (according to [20]). As such, their use in developing core chronologies for the Anthropocene is expected to increase.

But human impacts on most freshwater ecosystems started to be felt long before the mid-20th century. What is more, because of the essential services that they provide, freshwaters have always been disproportionately affected by human activities compared to other ecosystems. Today, they are among the most degraded and threatened ecosystems on Earth [29], their degradation outpacing the efforts to manage them [30]. Therefore, in most cases, evaluating the period of anthropogenic influence necessitates going back in time further than the Anthropocene proper, into what some are now calling the "Paleoanthropocene" [31]. The Paleoanthropocene is a useful concept in defining the varying timescales at which human processes have been regionally operating on particular ecosystems [19]. For the time being, it has the advantage of being flexible in its duration depending on the region of interest (although this might change in the future, as the term is very new). For example, the Paleoanthropocene in Beringia would have a longer duration than in Tierra del Fuego because of the timing of the arrival of humans in these regions through their initial migrations across the Americas. The term does not currently imply a specific degree of human impact on the environment, merely that human presence in a region be discernable through paleoenvironmental analysis.

Lake sediments often start to record signals of human activity almost as soon as they occur on the landscape. They are, therefore, often well-suited to determine the start of the Paleoanthropocene in different regions. The case of Australasia provides an example that illustrates the extreme temporal range over which the Paleoanthropocene can stretch within a given region. It also illustrates the wide degree of sensitivity that ecosystems can exhibit to human pressures on the landscape. 
Whereas ecosystems in New Zealand (NZ) remained untouched until the late arrival of the Māori, around 700 years ago, some ecosystems in neighbouring Australia have been subjected to human intervention for many thousands of years (e.g., [32]). Lake sediment studies in NZ show, based on sedimentary pollen assemblages and the abundance and size of charcoal particles, that soon after the arrival of humans on the South Island, human-set fires sparked a significant change in vegetation cover, with forests being replaced by shrub land that is still in place today. Precise dating of lake sediment sequences allowed for an accurate constraint of the timing of this shift to the first few decades of human presence [33]. The analysis of additional proxies from these sequences, including siliceous algae (diatoms), dipteran larvae (chironomids) and elemental concentrations, indicated that rapid human-induced landscape changes also had lasting effects on lakes themselves [34]. These paleolimnological studies, thus, make clear the low resilience of NZ ecosystems, both terrestrial and aquatic, to environmental perturbations caused by even small numbers of humans. On the other hand, impacts of human pressures by aboriginal populations on the aquatic ecosystems of Australia are not as straightforward, perhaps due to the vast timescale at which they have been operating. However, these ecosystems could also have a low sensitivity (i.e., high resistance and resilience) to anthropogenic actions. The sediments from wetlands of Southeastern Australia, for example, appear to have faithfully recorded marked past climate fluctuations at the millennial scale from which these systems have repetitively successfully recovered. However, many of these wetlands currently exhibit states that are outside their long-term historical range of variability. These new states point to recent human stressors, including hydrological modifications, as the cause of these unprecedented conditions [35]. It therefore appears that these wetlands are at equilibrium to a certain degree of natural environmental variation, but that the more intense, unprecedented actions of much more numerous humans on the landscape over the last century, have brought them into a new state that challenges managers and conservationists to determine if and how they will recover. These examples highlight the usefulness of lake sediment studies in gauging the natural and human environmental heritage of landscapes and ecosystems before and during the Paleoanthropocene as a benchmark against which to assess the direction and magnitude of changes in the Anthropocene.

\section{Determining Baseline Conditions Relevant to Environmental Sustainability}

One of the goals of environmental sustainability is to maintain ecosystems in a state that allows the needs of humans to be met while maintaining the quality of the environment on a long-term basis for use by future generations [36]. Such a state, where desirable goals, such as the maintenance of evolutionary and historical ecological processes inherent to the given system are met (see [34]), is often referred to as the health of an ecosystem. However, defining what a "healthy" ecosystem is inevitably generates a number of complex questions that must be addressed in order to determine the best way to maintain desired qualities into the future. How did a particular system function before significant anthropogenic impact? How resilient is the system to natural environmental variability and to human-induced change? To what degree has the system been modified from its natural state? These questions constitute some of the basic issues that must be resolved in order to set limits of acceptable change in ecosystem function and resilience capacity. The paleolimnological approach is better-suited to answer these questions than traditional monitoring of ecosystems on its own. Monitoring rarely covers long periods of time, and will often provide highly variable data that do not reveal meaningful trends in the magnitude and direction of change (e.g., [37]). However, long-term monitoring (>10 years) combined with the paleolimnological approach can provide an increased understanding of environmental dynamics and change (e.g., [38]).

In the field of impact assessment, baseline conditions are usually referred to as the initial environmental setting or existing conditions at the start of a study [39]. However, from the paleoenvironmental perspective, baseline conditions are defined as the past, non-degraded environmental setting against which to evaluate the direction and magnitude of subsequent human-induced change in a given ecosystem through time [40]. In short, they are most often viewed 
as the conditions that prevailed in a freshwater ecosystem before any significant human disturbance took place. But determining baseline conditions is not always straightforward, not just because it is sometimes difficult to determine the onset and degree of human impact, but also because ecosystems vary greatly through time from natural drivers. In many instances, distinguishing human impact from natural drivers of change can be challenging, especially when humans have been present in a region for an extended period of time. In such cases, pinpointing the time at which human impact becomes first discernable and then significant in the sediment record may become tricky. However, paleolimnological investigations do provide the long-term historical range of variability needed to contextualize more recent and intense human pressures (see above example concerning Australian ecosystems). Baseline assessments are, therefore, essential to gain a better understanding of how a system works without, or with little, influence of human activities and within a certain climatic context in order to better define and measure anthropogenic impacts.

Although in most cases it is unrealistic to hope to return ecosystems to their baseline conditions, paleolimnology can help to define "reference conditions," or the best attainable conditions that can be specifically targeted by restoration [40]. Determining baseline and reference conditions in lakes and their catchments can serve as the basis for a more in-depth understanding of the timing, magnitude and direction of environmental change, along with identifying the processes and implications of change (Figure 2). A classic example of how paleolimnology can inform restoration strategies by determining reference conditions and historical trajectories is the case of lake acidification. Smol [15] devoted an entire chapter to this subject, where he recounted in detail how, by using the paleolimnological approach, it was possible to trace the historical acidification of lakes due to atmospheric deposition of pollutants, such as sulfuric and nitric acids injected into the atmosphere by smelters (e.g., [41-43]). Paleolimnological studies provided the necessary data to differentiate lakes that were naturally acidic from lakes that were resistant to or highly sensitive to acidification, thereby informing restoration strategies of the potential capacity for recovery of lakes in specific regions (e.g., [44]). These different types of lakes, although having similar modern measured $\mathrm{pH}$ values, would evidently not necessitate the same restoration approaches and targets. For example, it would be pointless to set a goal to reach circumneutrality in a naturally acidic lake. However, without the knowledge provided by the paleolimnological approach, it would be impossible to tailor restoration targets and strategies for inherently different ecosystems that appear similar based only on short-term measurements and observations of abiotic variables.

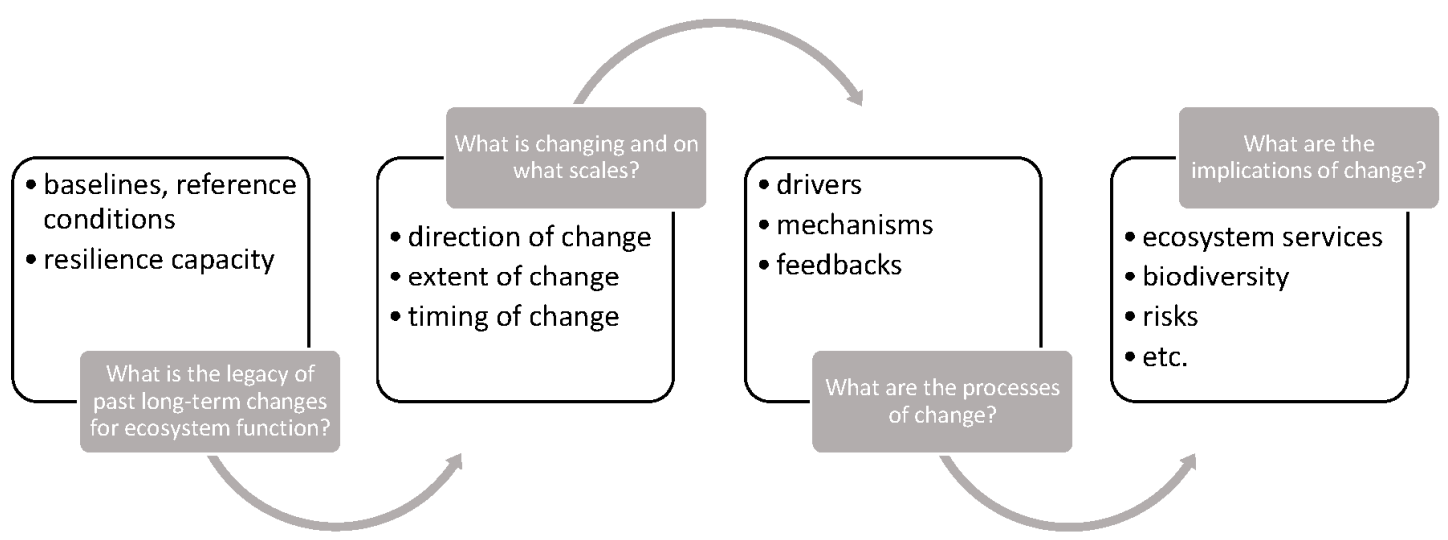

Figure 2. Synthesis of how the application of the paleolimnological approach can inform management and conservation of ecosystems.

Lake acidification is only one example of how paleolimnology can provide information on the timing and extent of human-induced environmental change in lakes and their catchments. The problem of cultural eutrophication of lakes, or the degradation of lake ecosystems by excessive production of plant and algal biomass caused by an oversupply of nutrients (mainly through runoff 
from wastewater and agricultural activities), is another global environmental problem that the paleolimnological approach has greatly contributed to elucidating (see [45] and citations therein). Although reference status in some eutrophied lake types is not always easy to establish with certainty (e.g., [46]), paleolimnological analyses will consistently provide targeted knowledge of the internal and external dynamics that shape ecosystem structure and functioning that would otherwise be impossible to obtain. As such, the paleolimnological approach is vital to providing indications of sound restoration targets and strategies (Figure 2).

\section{Past Quantitative Inferences of Environmental Variables}

In addition to inferring past trends in the $\mathrm{pH}$ of lake water, many of the studies on long-term lake acidification have also provided quantitative reconstructions of this variable over decadal to millennial timescales, indicating the extent and variability of acidification in various lakes. Quantitative inferences derived from multivariate statistical models based on modern biotic assemblage composition are a particularly powerful tool in paleolimnology. Their development, application and evaluation are described at length by Juggins and Birks [47]. Although the method does have its limits [48], if they are taken into careful consideration, the data that are generated through this technique can be extremely useful. The approach has been in use for the last few decades and has been refined over time and applied to lakes of all latitudes, from the Equator (e.g., [49]) to the poles (e.g., [50]). These quantitative inference models are based on current ecological preferences of microscopic organisms that preserve well in lake sediments (although they can also be constructed using biogeochemical markers in the sediment, like algal and bacterial pigments [51], or measured attributes of the chemical composition of organic materials by techniques such as near-infrared spectrometry [52]). For example, the chitinous remains of dipteran aquatic larvae, such as chironomids and chaoborids, can be useful to infer past changes in air and water temperature [53], oxygen content [54], water depth [55], turbidity [56] and the presence or absence of fish [57]. Siliceous diatom frustules are used to infer fluctuations in variables such as $\mathrm{pH}$ [41], salinity [58], dissolved organic carbon [59] and phosphorus [60]. Many of these variables are driven by climatic factors like temperature and humidity, and by direct and indirect human pressures on the landscape, including deforestation, erosion, land-use change, input of nutrients, atmospheric deposition of contaminants (e.g., heavy metals) and species introductions.

The capacity of lake sediments to preserve multiple proxies of environmental variables and processes (both aquatic and terrestrial) makes them a particularly valuable source of paleoenvironmental information. Multiproxy analysis has the advantage of providing several independent signals of environmental change that allow to validate inferences. Studies that encompass both terrestrial and aquatic indicators have a strong potential to present a holistic view of long-term environmental change by tracing networks of interactions between the various components of the studied system (see [61]). But as anthropogenic impacts become more widespread and diverse, enhanced synergistic changes (i.e., complex responses linked to interactions between natural and human-induced pressures) are taking place in freshwater ecosystems and their catchments. Lake sediment studies have the advantage that they can encompass the total effects of multiple stressors, but, moreover, there are statistical approaches that allow for the disentangling of the effects of various environmental variables on paleolimnological proxies [62], and thereby making it possible to better identify the key driver(s) of change.

In addition to providing better knowledge of environmental processes at the local and regional scales, paleolimnology is becoming increasingly useful in determining global mechanisms in geochemical cycles. Lakes process and store large amounts of organic carbon, which means that they can influence climatic feedbacks in relation to their potential greenhouse gas emissions or sequestration. Recently, McGowan et al. [12] reviewed how paleolimnological studies can contribute to the interpretation of carbon cycling through terrestrial-atmospheric-aquatic linkages. Furthermore, a paleolimnological study by Heathcote et al. [63] showed a significant increase in organic carbon burial rates in boreal lakes over the Anthropocene, suggesting major shifts in the overall biogeochemical 
functioning of northern landscapes. These disruptions to lake biochemistry have implications for understanding how lakes and their watersheds will function in the future, and must be taken into account for effective planning and management at various spatial scales.

\section{Recent Developments in Paleolimnology Pave the Way for Future Sustainability}

One of the shortcomings of traditional paleolimnology, which relies heavily on biological remains, is that only a fraction of organisms have the potential to be preserved in lake sediments. Most of these are primary producers, consumers and detritivores as well as invertebrate secondary consumers. Fish, unfortunately, do not produce adequate subfossils. However, organisms leave behind chemical and molecular tracers of their presence in lake sediments, and paleolimnologists have been able to tap into these resources. Sedimentary pigments, for example, are a reliable biochemical record of past algal and bacterial communities in lakes [64], and have been used successfully for many years in paleoenvironmental studies [65]. Sedimentary pigments are proving to be particularly relevant to address many current global environmental concerns about aquatic ecosystem health. These include tracing the recent proliferation of cyanobacteria in temperate lakes and identifying its causes [66] and understanding the abatement of primary production in tropical lakes accompanying recent climate warming [67]. Another useful biogeochemical marker is the isotopic composition of sediment (carbon, nitrogen) and of some of its different fractions (such as the stable carbon isotopes in cellulose and the oxygen isotopes in calcite and biogenic silica). Isotopic analysis of lake sediments provides diverse paleoenvironmental information, but is particularly useful to reconstruct past climate, especially as it relates to hydrological changes in lakes and their catchments (see [68]).

Recently, scientists have been developing powerful molecular techniques to trace the past presence of organisms in lakes $[69,70]$. This approach has the potential to shed light on many aspects of long-term environmental change that were difficult to explore in the past and are relevant to the sustainable management of ecosystems. A telling example of this is a recent study by Stager et al. [71] that used sedimentary DNA to show that yellow perch, a fish believed to have been introduced and considered an invasive species in lakes of Northern New York (USA), is actually a native species that has been present in the lakes of this region for over 2200 years. Results such as this can completely change the status of certain species and help to design better strategies for biodiversity conservation and fisheries management. Through studies that define the drivers of change in species richness and that quantify the impact of environmental variables on community structure at various temporal scales, paleolimnology can, in fact, provide greater insight into biodiversity dynamics and environmental change through time [72].

\section{Conclusions}

In summary, the legacy of past long-term changes, including natural variability and human-induced changes, in freshwater ecosystems and their catchments has important implications for their current and future dynamics. By accounting for this heritage, environmental management gains a better perspective of what types of interventions need to be applied to obtain the best possible results in order to maintain or recover ecosystem services. Paleolimnology can contribute significantly to a deeper understanding of the long-term functioning and resilience of these ecosystems and can refine knowledge to improve best practices. It is, therefore, essential that the long-term approach be increasingly integrated into environmental assessment and management in order to help reduce uncertainty regarding natural processes and resilience capacity, thereby improving environmental sustainability.

Acknowledgments: I thank Isabelle Lavoie and Stéphane Boudreau for providing valuable input. The comments and suggestions of three referees greatly improved the manuscript.

Conflicts of Interest: The author declares no conflict of interest. 


\section{References}

1. Gillson, L.; Marchant, R. From myopia to clarity: Sharpening the focus of ecosystem management through the lens of paleoecology. Trends Ecol. Evol. 2014, 29, 317-325. [CrossRef] [PubMed]

2. Jackson, S.T.; Hobbes, R.J. Ecological restoration in the light of ecological history. Science 2009, 325, 567-568. [CrossRef] [PubMed]

3. Willis, K.J.; Araujo, M.B.; Bennett, K.D.; Figueroa-Rangel, B.; Froyd, C.A.; Myers, N. How can a knowledge of the past help to conserve the future? Biodiversity conservation and the relevance of long-term ecological studies. Philos. Trans. R. Soc. B 2007, 362, 175-186. [CrossRef] [PubMed]

4. Saulnier-Talbot, É. Overcoming the disconnect: Are paleolimnologists doing enough to make their science accessible to aquatic managers and conservationists? Front. Ecol. Evol. 2015, 3. [CrossRef]

5. Schindler, D.W. Lakes as sentinels and integrators for the effects of climate change on watersheds, airsheds and landscapes. Limnol. Oceanogr. 2009, 54, 2349-2358. [CrossRef]

6. Williamson, C.E.; Saros, J.E.; Vincent, W.F.; Smol, J.P. Lakes and reservoirs as sentinels, integrators and regulators of climate change. Limnol. Oceanogr. 2009, 54, 2273-2282. [CrossRef]

7. Verschuren, D.; Laird, K.R.; Cumming, B.F. Rainfall and drought in equatorial east Africa during the past 1100 years. Nature 2000, 403, 410-414. [CrossRef] [PubMed]

8. Roberts, N.; Jones, M.D.; Benkaddour, A.; Eastwood, W.J.; Filippi, M.L.; Frogley, M.R.; Lamb, H.F.; Leng, M.J.; Reed, J.M.; Stein, M.; et al. Stable isotope records of Late Quaternary climate and hydrology from Mediterranean lakes: The ISOMED synthesis. Quat. Sci. Rev. 2008, 27, 2426-2441. [CrossRef]

9. Michelutti, N.; Wolfe, A.P.; Vinebrooke, R.D.; Rivard, B.; Briner, J.P. Recent primary production increases in Arctic lakes. Geophys. Res. Lett. 2005, 32, L19715. [CrossRef]

10. Saulnier-Talbot, É.; Pienitz, R.; Vincent, W.F. Holocene lake succession and palaeo-optics of a subarctic lake, northern Québec (Canada). Holocene 2003, 13, 517-526. [CrossRef]

11. Hu, F.S.; Finney, B.P.; Brubaker, L.B. Effects of Holocene Alnus expansion on aquatic productivity, nitrogen cycling and soil development in southwestern Alaska. Ecosystems 2001, 4, 358-368. [CrossRef]

12. McGowan, S.; Anderson, N.J.; Edwards, M.E.; Langdon, P.G.; Jones, V.J.; Turner, S.; van Hardenbroek, M.; Whiteford, E.; Wiik, E. Long-term perspectives on terrestrial and aquatic carbon cycling from paleolimnology. WIREs Water 2015, 3, 211-234. [CrossRef]

13. Quinlan, R.; Hall, R.I.; Paterson, A.M.; Cumming, B.F.; Smol, J.P. Long-term assessments of ecological effects of anthropogenic stressors on aquatic ecosystems from paleoecological analyses: Challenges to perspectives of lake management. Can. J. Fish. Aquat. Sci. 2008, 65, 933-944. [CrossRef]

14. Frey, D.G. What is paleolimnology? J. Paleolimnol. 1988, 1, 5-8. [CrossRef]

15. Smol, J.P. Pollution of Lakes and Rivers A Paeloenvironmental Perspective, 2nd ed.; Blackwell Publishing: Oxford, UK, 2008; pp. 88-119.

16. Smeltzer, E.; Swain, E.B. Answering lake management questions with paleolimnology. In Lake and Reservoir Management: Practical Applications, Proceedings of the Fourth Annual Conference and International Symposium of the North American Lake Management Society, McAfee, NJ, USA, 16-19 October 1984; pp. 268-274.

17. Smol, J.P. Paleolimnology: An important tool for effective ecosystem management. J. Aquat. Ecosyst. Health 1992, 1, 49-58. [CrossRef]

18. Saulnier-Talbot, É.; Pienitz, R.; Stafford, T.W., Jr. Establishing Holocene sediment core chronologies for northern Ungava lakes, Canada, using humic acids (AMS 14C) and 210Pb. Quat. Geochronol. 2009, 4, 278-287. [CrossRef]

19. Corlett, R.T. The Anthropocene concept in ecology and conservation. Trends Ecol. Evol. 2015, 30, 36-41. [CrossRef] [PubMed]

20. Waters, C.N.; Zalasiewicz, J.; Summerhayes, C.; Barnosky, A.D.; Poirier, C.; Gałuszka, A.; Cearreta, A.; Edgeworth, M.; Ellis, E.C.; Ellis, M.; et al. The Anthropocene is functionally and stratigraphically distinct from the Holocene. Science 2016, 351. [CrossRef] [PubMed]

21. Hibbard, K.A.; Crutzen, P.J.; Lambin, E.F.; Liverman, D.; Mantua, N.J.; McNeill, J.R.; Messerli, B.; Steffen, W. Decadal interactions of humans and the environment. In Integrated History and Future of People on Earth; Costanza, R., Graumlich, L., Steffen, W., Eds.; Dahlem Workshop Report 96; MIT Press: Cambridge, MA, USA, 2006; pp. 341-375. 
22. Steffen, W.; Broadgate, W.; Deutsch, L.; Gaffney, O.; Ludwig, C. The trajectory of the Anthropocene: The great acceleration. Anthr. Rev. 2015, 2, 81-98. [CrossRef]

23. Saulnier-Talbot, É.; Larocque-Tobler, I.; Gregory-Eaves, I.; Pientiz, R. Response of lacustrine biota to Late Holocene climate and environmental conditions in northernmost Ungava (Canada). Arct. Inst. N. Am. 2015, 68, 153-168. [CrossRef]

24. Hobbes, W.O.; Telford, R.J.; Birks, H.J.B.; Saros, J.E.; Hazewinkel, R.R.O.; Perren, B.B.; Saulnier-Talbot, É.; Wolfe, A.P. Quantifying recent ecological changes in remote lakes of North America and Greenland using sediment diatom assemblages. PLoS ONE 2010, 5, e10026. [CrossRef] [PubMed]

25. Catalan, J.; Pla-Rabés, S.; Wolfe, A.P.; Smol, J.P.; Rühland, K.M.; Anderson, N.J.; Kopáček, J.; Stuchlík, E.; Schmidt, R.; Koinig, K.A.; et al. Global change revealed by palaeolimnological records from remote lakes: A review. J. Paleolimnol. 2013, 49, 513-539. [CrossRef]

26. Wolfe, A.P.; Hobbs, W.O.; Birks, H.H.; Briner, J.P.; Holmgren, S.U.; Ingólfsson, Ó.; Kaushal, S.S.; Miller, G.H.; Pagani, M.; Saros, J.E.; et al. Stratigraphic expressions of the Holocene-Anthropocene transition revealed in sediments from remote lakes. Earth Sci. Rev. 2013, 116, 17-34. [CrossRef]

27. Rose, N. Fly-ash particles. In Tracking Environmental Change Using Lake Sediments, Volume 2, Physical and Chemical Methods; Last, W.M., Smol, J.P., Eds.; Kluwer Academic Publishers: Dordrecht, The Netherlands, 2001; pp. 319-349.

28. Rose, N. Spheroidal carbonaceous fly ash particles provide a globally synchronous stratigraphic marker for the Anthropocene. Environ. Sci. Technol. 2015, 49, 4155-4162. [CrossRef] [PubMed]

29. World Wildlife Fund. Living Planet Report, 2014. Available online: http://wwf.panda.org/about_our_ earth/all_publications/living_planet_report/ (accessed on 27 January 2016).

30. Ormerod, S.J.; Dobson, M.; Hildrew, A.G.; Townsend, C.R. Multiple stressors in freshwater ecosystems. Freshw. Biol. 2010, 55, 1-4. [CrossRef]

31. Foley, S.F.; Gronenborn, D.; Andreae, M.O.; Kadereit, J.W.; Esper, J.; Scholz, D.; Pöschl, U.; Jacob, D.E.; Schöne, B.R.; Schreg, R.; et al. The Palaeoanthropocene-The beginnings of anthropogenic environmental change. Anthropocene 2013, 3, 83-88. [CrossRef]

32. Turney, C.S.M.; Kershaw, P.; Moss, B.; Bird, M.I.; Fifield, L.K.; Cresswell, R.G.; Santos, G.M.; Di Tada, M.L.; Hausladen, P.A.; Zhou, Y. Redating the onset of burning at Lynch's crater (North Queensland): Implications for human settlement in Australia. J. Quat. Sci. 2001, 16, 767-771. [CrossRef]

33. McWethy, D.B.; Wilmshurst, J.M.; Whitlock, C.; Wood, J.R.; McGlone, M.S. A high-resolution chronology of rapid forest transitions following Polynesian arrival in New Zealand. PLoS ONE 2014, 9, e111328. [CrossRef] [PubMed]

34. McWethy, D.B.; Whitlock, C.; Wilmshurst, J.M.; McGlone, M.S.; Fromont, M.; Li, X.; Dieffenbacher-Krall, A.; Hobbs, W.O.; Fritz, S.C.; Cook, E.R. Rapid landscape transformation in South Island, New Zealand, following initial Polynesian settlement. PNAS 2010, 107, 21343-21348. [CrossRef] [PubMed]

35. Gell, P.; Mills, K.; Grundell, R. A legacy of climate and catchment change: The real challenge for wetland management. Hydrobiology 2012, 708, 133-144. [CrossRef]

36. Kates, R.W.; Parris, T.M.; Leiserowitz, A.A. What is sustainable development? Goals, indicators, values and practice. Environ. Sci. Policy Sustain. Dev. 2005, 47, 8-21.

37. Grumbine, R.E. What is ecosystem management? Conserv. Biol. 1994, 8, 27-38. [CrossRef]

38. Brenner, M.; Whitmore, T.J.; Flannery, M.S.; Binford, M.W. Paleolimnological methods for defining target conditions in lake restoration: Florida case studies. Lake Reserv. Manag. 1993, 7, 209-217. [CrossRef]

39. Shepard, R.B. Quantifying environmental impact assessments using fuzzy logic. In Springer Series on Environmental Management; Springer: Berlin, Germany, 2006; p. 264.

40. Bennion, H.; Battarbee, R.W.; Sayer, C.D.; Simpson, G.L.; Davidson, T.A. Defining reference conditions and restoration targets for lake ecosystems using palaeolimnology: A synthesis. J. Paleolimnol. 2010, 45, 533-544. [CrossRef]

41. Dixit, A.S.; Dixit, S.S.; Smol, J.P. Long-term trends in lake water $\mathrm{pH}$ and metal concentrations inferred from diatoms and chrysophytes in three lakes near Sudbury, Ontario. Can. J. Fish. Aquat. Sci. 1992, 49, 17-24. [CrossRef]

42. Renberg, I.; Korsman, T.; Anderson, N.J. A temporal perspective of lake acidification in Sweden. Ambio 1993, $22,264-271$. 
43. Hodgson, D.A.; Vyverman, W.; Chepstow-Lusty, A.; Tyler, P.A. From rainforest to wasteland in 100 years: The limnological legacy of the Queenston mines, Western Tasmania. Arch. Hydrobiol. 2000, 149, 153-176.

44. Smol, J.P.; Cumming, B.F.; Dixit, A.S.; Dixit, S.S. Tracking recovery patterns in acidified lakes: A paleolimnological perspective. Restor. Ecol. 1998, 6, 318-326. [CrossRef]

45. Battarbee, R.W.; Bennion, H. Paleolimnology and its developing role in assessing the history and extent of human impact on lake ecosystems. J. Paleolimnol. 2011, 45, 399-404. [CrossRef]

46. Wiik, E.; Bennion, H.; Sayer, C.D.; Davidson, T.A.; Clake, S.J.; McGowan, S.; Prentice, S.; Simpson, G.L.; Stone, L. The coming and going of a marl lake: Multi-indicator paleolimnology reveals abrupt ecological change and alternative views of reference conditions. Front. Ecol. Evol. 2015, 3. [CrossRef]

47. Juggins, S.; Birks, H.J.B. Quantitative environmental reconstructions from biological data. In Tracking Environmental Change Using Lake Sediments, Volume 5, Data Handling and Numerical Techniques; Birks, H.J.B., Lotter, A.F., Juggins, S., Smol, J.P., Eds.; Kluwer Academic Publishers: Dordrecht, The Netherlands, 2012; pp. 431-494.

48. Juggins, S. Quantitative reconstructions in paleolimnology: New paradigm or sick science? Quat. Sci. Rev. 2013, 64, 20-32. [CrossRef]

49. Eggermont, H.; Heiri, O.; Verschuren, D. Fossil Chironomidae (Diptera) as quantitative indicators of past salinity in African lakes. Quat. Sci. Rev. 2006, 25, 1966-1994. [CrossRef]

50. Antoniades, D.; Douglas, M.S.V.; Smol, J.P. Benthic diatom autoecology and inference model development from the Canadian High Arctic Archipelago. J. Phycol. 2005, 41, 30-45. [CrossRef]

51. Guilizzoni, P.; Marchetto, A.; Lami, A.; Gerli, S.; Musazzi, S. Use of sedimentary pigments to infer past phosphorus concentrations in lakes. J. Paleolimnol. 2011, 45, 433-445. [CrossRef]

52. Rosén, P.; Dåbakk, E.; Renberg, I.; Nilsson, M.; Hall, R. Near-infrared spectrometry (NIRS): A new tool for inferring past climatic changes from lakes sediments. Holocene 2000, 10, 161-166. [CrossRef]

53. Larocque, I.; Pientiz, R.; Rolland, N. Factors influencing the distribution of chironomids in lakes distributed along a latitudinal gradient in northwestern Quebec, Canada. Can. J. Fish. Aquat. Sci. 2006, 63, 1286-1297. [CrossRef]

54. Luoto, T.P.; Salonen, V.-P. Fossil midge larvae (Diptera: Chironomidae) as quantitative indicators of late-winter hypolimnetic oxygen in southern Finland: A calibration model, case studies and potentialities. Boreal Environ. Res. 2010, 15, 1-18.

55. Korhola, A.; Olander, H.; Blom, T. Cladoceran and chironomid assemblages as qualitative indicators of water depth in subarctic Fennoscandian lakes. J. Paleolimnol. 2000, 24, 43-54. [CrossRef]

56. Greffard, M.-H.; Saulnier-Talbot, É.; Gregory-Eaves, I. Subfossil chironomids are significant indicators of turbidity in shallow lakes of northeastern USA. J. Paleolimnol. 2012, 47, 561-581. [CrossRef]

57. Sweetman, J.N.; Smol, J.P. Reconstructing fish populations using Chaoborus (Diptera: Chaoboridae) remains -A review. Quat. Sci. Rev. 2006, 25, 2013-2023. [CrossRef]

58. Wilson, S.E.; Cumming, B.F.; Smol, J.P. Diatom-salinity relationships in 111 lakes from the Interior Plateau of British Columbia, Canada: The development of diatom-based models for paleosalinity reconstructions. J. Paleolimnol. 1994, 12, 197-221. [CrossRef]

59. Fallu, M.-A.; Pienitz, R. Diatomées lacustres de Jamésie-Hudsonie (Québec) et modèle de reconstitution des concentrations de carbone organique dissous. Ecoscience 1999, 6, 603-620.

60. Cumming, B.F.; Laird, K.R.; Gregory-Eaves, I.; Simpson, K.G.; Sokal, M.A.; Nordin, R.; Walker, I.R. Tracking past changes in lake-water phosphorus with a 251-lake calibration dataset in British Columbia: Tool development and application in a multiproxy assessment of eutrophication and recovery in Osoyoos Lake, a transboundary lake in western North America. Front. Ecol. Evol. 2015, 3, 84. [CrossRef]

61. Birks, H.H.; Briks, H.J.B. Multiproxy studies in paleolimnology. Veg. Hist. Archeobot. 2006, 15, $235-251$. [CrossRef]

62. Simpson, G.L.; Anderson, N.J. Deciphering the effect of climate change and separating the influence of confounding factors in sediment core records using additive models. Limnol. Oceanogr. 2009, 54, 2529-2541. [CrossRef]

63. Heathcote, A.; Anderson, N.J.; Prairie, Y.T.; Engstrom, D.R.; del Giorgio, P.A. Large increases in carbon burial in northern lakes during the Anthropocene. Nat. Commun. 2015, 6, 10016. [CrossRef] [PubMed]

64. Leavitt, P.R. A review of factors that regulate carotenoid and chlorophyll deposition and fossil pigment abundances. J. Paleolimnol. 1993, 9, 109-127. [CrossRef] 
65. Leavitt, P.R.; Hodgson, D.A. Sedimentary pigments. In Tracking Environmental Change Using Lake Sediments, Volume 3, Terrestrial, Algal and Siliceous Indicators; Smol, J.P., Birks, H.J.B., Last, W.M., Eds.; Kluwer Academic Publishers: Dordrecht, The Netherlands, 2001; pp. 295-325.

66. Taranu, Z.E.; Gregory-Eaves, I.; Leavitt, P.; Bunting, L.; Buchaca, T.; Catalan, J.; Domaizon, I.; Guilizzoni, P.; Lami, L.; McGowan, S.; et al. Acceleration of cyanobacterial dominance in north temperate-subarctic lakes during the Anthropocene. Ecol. Lett. 2015, 18, 375-384. [CrossRef] [PubMed]

67. Saulnier-Talbot, É.; Gregory-Eaves, I.; Efitre, J.; Simpson, K.G.; Nowlan, T.E.; Taranu, Z.E.; Chapman, L.J. Small changes in climate can profoundly alter the dynamics and ecosystem services of tropical crater lakes. PLOS ONE 2014, 9, e86561. [CrossRef]

68. Leng, M.J.; Lamb, A.L.; Heaton, T.H.E.; Marshall, J.D.; Wolfe, B.B.; Jones, M.D.; Holmes, J.A.; Arrowsmith, C. Isotopes in lake sediments. In Developments in Paleoenvironmental Research, Volume 10, Isotopes in Paleoenvironmental Research; Leng, M.J., Ed.; Kluwer Academic Publishers: Dordrecht, The Netherlands, 2006; pp. 147-184.

69. Gregory-Eaves, I.; Domaizon, I. Analysis of DNA archived in lake sediments. ASLO E Lect. 2014. [CrossRef]

70. Pal, S.; Gregory-Eaves, I.; Pick, F.R. Temporal trends in cyanobacteria revealed through DNA and pigments analyses of temperate lake sediment cores. J. Paleolimnol. 2015, 54, 87-101. [CrossRef]

71. Stager, J.C.; Sporn, L.A.; Johnson, M.; Regalado, S. Of paleo-genes and perch: What if an "alien" is actually a native? PLoS ONE 2015, 10. [CrossRef] [PubMed]

72. Gregory-Eaves, I.; Beisner, B. Palaeolimnological insights for biodiversity science: An emerging field. Freshw. Biol. 2011, 56, 2653-2661. [CrossRef]

(c) 2016 by the author; licensee MDPI, Basel, Switzerland. This article is an open access article distributed under the terms and conditions of the Creative Commons Attribution (CC-BY) license (http://creativecommons.org/licenses/by/4.0/). 